\title{
Scan-to-HBIM e Gis per la documentazione dei beni culturali: un'utile integrazione
}

\author{
Sara Gonizzi Barsanti \\ Adriana Rossi
}

\begin{abstract}
L'utilizzo dei GIS per la gestione di dati geo-spaziali di Beni Culturali, integrati alle procedure Scanto-HBIM, si dimostra un utilissimo strumento sia per l'archiviazione e consultazione, sia per la conservazione dei manufatti. Questa infatti si lega strettamente alla regolare manutenzione di tali edifici. Per realizzarla in modo efficace è necessario disporre di uno strumento che consenta di raccogliere, confrontare e condividere tutti i dati disponibili sulle loro dimensioni, sullo stato di conservazione attuale e sulle attività di manutenzione o restauro eseguite nel tempo. I modelli 3D derivati dai rilievi diventano base del progetto di conservazione e tutela, molto più efficaci se inseriti in un GIS 'contenitore' delle molteplici informazioni, suddivise in specifiche e univoche categorie (oggetti). Ogni modello viene direttamente corredato, collegati alle definizioni geometriche, dai dati alfanumerici relativi (localizzazione, materiali, caratteristiche tecniche, aspetto manutentivo, analisi strutturali, stima dei costi per il restauro etc.). Un Sistema Informativo così formato comporta la segmentazione dei modelli tridimensionali reali nelle loro parti strutturali e decorative, singolarmente trasformate in componenti HBIM. Esso diviene così costantemente implementabile ed interrogabile, non come semplice catalogo di informazioni, ma anche e soprattutto strumento capace di garantire attività di estrazione, combinazione e condivisione di tutte le parti necessarie.
\end{abstract}

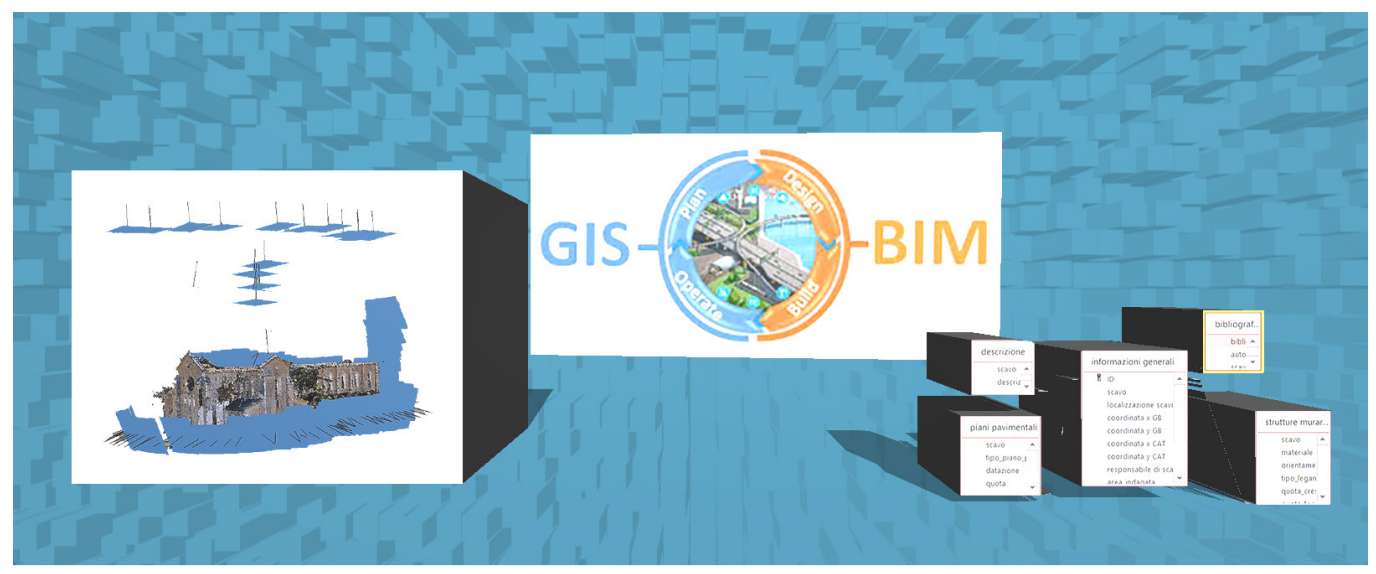




\section{Introduzione}

Per la tutela dei Beni Culturali [ I ] il primo passo necessario è la corretta ed accurata documentazione, completa di tutte le analisi necessarie per consegnare ai gestori dei beni stessi lo strumento più adatto per intervenire correttamente. Ottimo strumento di documentazione è quello basato sulle misurazioni ottiche in tre dimensioni, che rappresentano uno strumento versatile e rigoroso. Tre sono le metodologie di acquisizione ottica 3D:

I. tecniche basate su sensori passivi (metodi image-based) come per esempio la fotogrammetria;

2. tecniche basate su sensori attivi (metodi range-based) come per esempio il laser scanning;

3. la combinazione di entrambe le tecniche.

Come è noto, la scelta della tecnica migliore e più appropriata dipende dall'oggetto o dall'area indagata, dall'esperienza dell'utilizzatore, dal budget, dal tempo a disposizione e dagli obiettivi prefissati. La tecnica fotogrammetrica permette di aggiungere, ad un'accurata descrizione geometrica in tre dimensioni, la ricchezza fornita dal contenuto radiometrico. Spesso, i rilievi fotogrammetrici sono una soluzione ottimale per eseguire l'indagine in modo economico e in tempi brevi con l'utilizzo di camere non metriche digitali, attentamente calibrate con appropriati e specifici algoritmi e procedure. I sensori attivi, come la scansione laser, sono utilizzati per eseguire l'indagine rigorosa di un oggetto o di un sito poiché, fornendo nuvole di punti 3D che possono essere unite con precisione, consentono di ottenere l'esatta copia, metrica [2], dell'oggetto scansionato, direttamente in tre dimensioni.

Merita ricordare che tra le principali applicazioni della modellazione tridimensionale, già ampiamente in uso come supporto alla conoscenza, conservazione, valorizzazione e restauro nel campo dei Beni Culturali vi sono in particolare quelle orientate alla catalogazione e visualizzazione degli oggetti considerati, alla conoscenza e analisi degli stessi e, più operativamente, alla Computer Aided Restoration. La digitalizzazione del processo risulta in fase già avanzata, ma accenneremo nel seguito a come queste tipologie di applicazioni potrebbero essere ulteriormente valorizzate. Inoltre è bene ancora osservare che grande potenzialità comunicativa è consentita da quelle applicazioni, fra queste citate, che rendono 'immersiva' la visualizzazione dei modelli costruiti come rappresentazione della realtà indagata. Esperienze da noi precedentemente condotte [Rossi 20 I 2; Rossi 20 I4; Rossi 20 I9], in circostanze e tempi differenti, su vari oggetti di valore storico e architettonico, hanno quindi stimolato lo sviluppo di questa indagine che presentiamo.

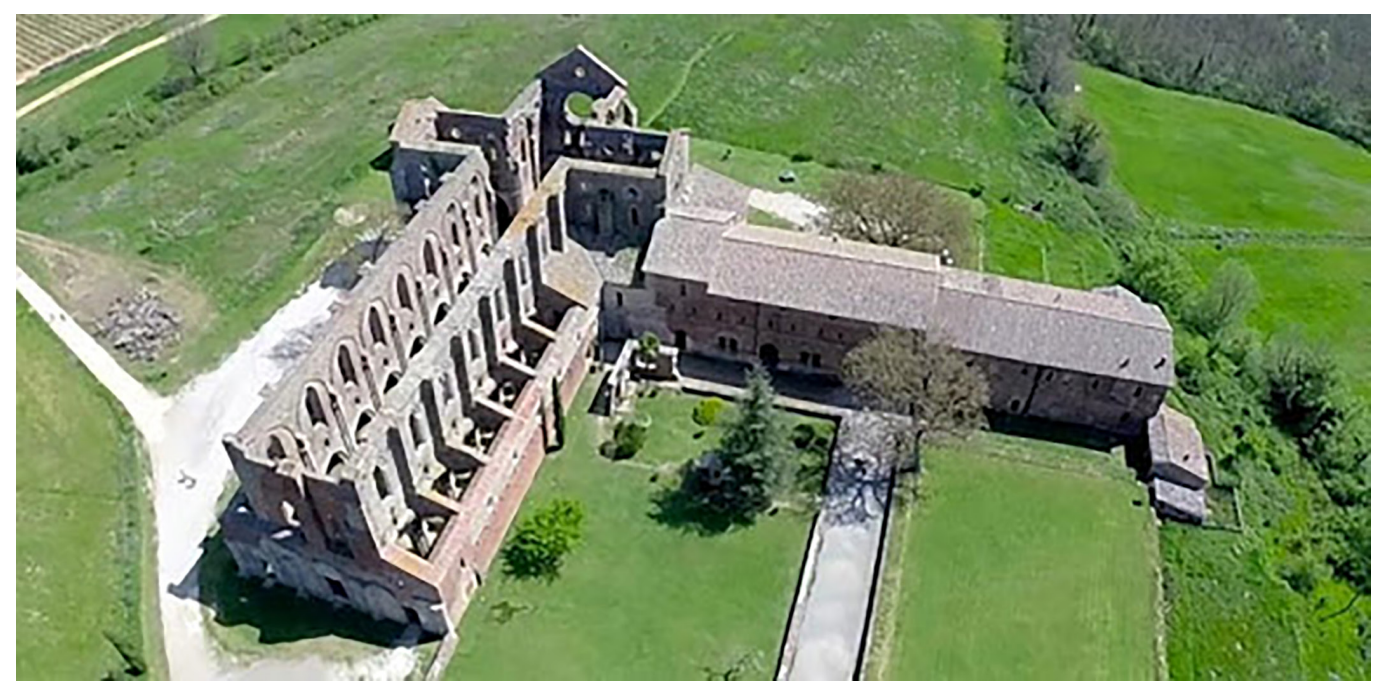




\section{Evoluzioni recenti}

I modelli 3D derivati dai rilievi possono essere inseriti in un GIS [Colucci 2020] partendo dalla segmentazione dei modelli tridimensionali reali nelle loro parti strutturali e decorative all'interno di software BIM. Tali parti costituiranno un database costantemente implementabile [3] ed interrogabile nel ciclo di vita del manufatto, realizzando un catalogo di informazioni, utilizzabile anche per la combinazione e condivisione delle stesse. Importando, nel software con cui si gestisce il processo BIM, le nuvole di punti 3D ottenute dal rilievo diretto, i componenti dell'edificio o del complesso architettonico indagato, creati utilizzando le classi IFC (BIM Industry Foundation Classes), si realizza una loro rappresentazione che costituisce sia modellazione geometrica coerente della realtà, sia contenitore di descrizioni semantiche, parametriche e di relazione dei suoi elementi [Previtali 2020] [4].

Per la gestione di modelli di manufatti culturali si parla ormai generalmente di HBIM (Historic Building Information System), considerando che per queste costruzioni la difficoltà di realizzazione digitale risiede nella complessità intrinseca di tali monumenti antichi. Essi infatti sono spesso composti da elementi costruttivi difficilmente riproducibili con oggetti ottenuti da produzioni modulari standardizzate: le strutture murarie, ad esempio, sono spesso comprensive di lesene, semi pilastri, cornici; gli orizzontamenti frequentemente realizzati con volte e sostenute da archi che da piano a piano possono cambiare di forma e dimensioni. Per questo il rilievo del costruito viene eseguito per fornire una nuvola di punti 3D metricamente accurata del reale [Yang 2019; Banfi 20 I7]. Le metodologie più comunemente adottate per l'operazione di rilievo sono realizzate con strumentazione laser-scanner o mediante fotogrammetria; post-processamento dei dati per realizzare la nuvola di punti tridimensionale completa del manufatto; modellazione dell'oggetto in ambiente BIM avendo come guida la nuvola di punti del fabbricato stesso (Scanto-HBIM). Ultimamente, gruppi di ricercatori e sviluppatori hanno iniziato a utilizzare soluzioni in grado di includere oltre alle informazioni metriche, la raccolta di informazioni storiche, tecnologiche, architettoniche referenziandole al modello digitale o raster e a gestirle su piattaforme open source, evitando software proprietari [Diara 2020; Logothetis 20 I7; Logothetis 20 I 8]. II principale problema che si incontra quando si vuole integrare i GIS con gli HBIM consiste nel fatto che i due sistemi gestiscono dati con livelli di dettaglio diversi. I GIS infatti, sono originariamente nati dall'esigenza di raccogliere, elaborare, gestire un'enorme mole di dati e informazioni territoriali, mentre i sistemi BIM, inizialmente definiti da una evoluzione delle rappresentazioni $C A D$, sono stati prevalentemente realizzati per gestire un insieme di informazioni finalizzate alle decisioni da assumere nel campo della progettazione architettonica. II metodo migliore che già si evidenzia in lavori recenti è quindi quello di unire i due sistemi in un'unica piattaforma, che sia in grado di passare attraverso i diversi livelli di dettaglio [Bruno 2020].

\section{Metodologia}

La metodologia Scan-to-HBIM prevede di fatto numerosi passaggi, realizzati mediante diversi software. Analizziamone un tipico esempio, in cui il primo passaggio, come già si è visto, consiste nell'acquisizione 3D della geometria del manufatto attraverso tecniche reality-based. II caso-studio che citiamo si riferisce all'abbazia di San Galgano in provincia di Siena [5] (fig. I). L'edificio è stato rilevato tramite tecnica fotogrammetrica terrestre e da drone, per ottenere un modello completo. Le due sessioni di rilievo sono poi state processate col software Agisoft Metashape, che utilizza la Structure from Motion (SfM) per ottenere una nuvola di punti 3D. II software allinea inizialmente le fotografie, calcolandone le posizioni nello spazio e contemporaneamente calibrando i parametri interni della macchina fotografia, passaggio fondamentale per ottenere immagini non distorte. Successivamente si può calcolare la nuvola densa del rilievo che, nel caso dell'abbazia, alla fine del procedimento è risultata composta da più di 15 milioni di punti (fig. 2).

Una volta creato il modello 3D come nel caso citato, si può procedere alla sua importazione in ambiente BIM per i successivi passaggi di modellazione parametrica, necessari per avere un modello, completo ma leggero e gestibile in ambiente GIS. 
Fig. 2. La nuvola di punti densa ricavata nel software SPM con l'unione del rilievo terrestre e da UAV con indicate le posizioni deg scatti (rettangoli blu).

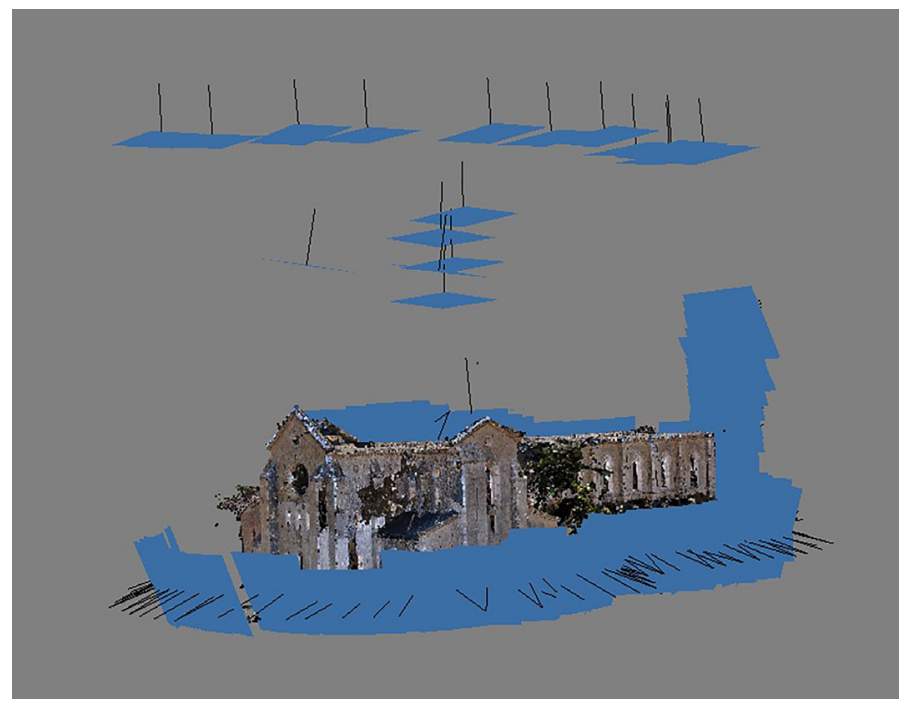

Oggi il software maggiormente usato per la modellazione BIM/HBIM è sicuramente Revit di Autodesk, che permette di importare nuvole di punti, create esternamente con software specifici, per poi essere rimodellate e analizzate. Questo passaggio presenta attualmente un problema, in quanto Revit legge solo ed esclusivamente due formati, *.rcs ed *.rcp, mentre il software fotogrammetrico esporta nei comuni formati (*.ply, *.obj, *.xyz) nonché in alcuni formati compatibili con software CAD. Per poter trasformare il file fotogrammetrico in uno compatibile con il software BIM si è pertanto dovuti passare attraverso un altro software della Autodesk, Recap, che leggendo i file *.xyz è in grado di esportarli nel formato compatibile con Revit (fig. 3).

Due sono le procedure solitamente utilizzare per modellare una nuvola di punti 3D in modo da renderla adatta ad essere utilizzata come modello parametrico in un software BIM:

a. importare la nuvola in un software di modellazione come Autocad o Rhinoceros, creare profili, modellare l'edificio tramite superfici o NURBS e importare poi questo modello in un software BIM;

b. utilizzare la modellazione parametrica orientata agli oggetti utilizzando direttamente i processi BIM [Tommasi 20I6].

Come visto, la possibilità di ottenere modelli parametrici, suddivisi in classi specifiche con proprie caratteristiche ed informazioni è un elemento fondamentale per l'utilizzo degli HBIM nella conservazione e per il restauro dei beni culturali e per questo motivo recentemente diverse ricerche ne stanno analizzando in modo approfondito le varie potenzialità [Pepe 2020; Previtali 2020].

Sicure utilità per la documentazione in forma digitale di complessi architettonici potranno realizzarsi anche nel corretto collegamento di questi modelli a un ambiente GIS. La difficoltà in questi passaggi è ancora dovuta al fatto che i due tipi di sistema gestiscono dati a scale diverse: ambientali quelle dei GIS, strutturali quelle dell'HBIM. Per ora, il legame tra le due metodologie avviene a livello di database relazionale interoperabile e multi-scala, che risponda alla necessità di archiviare e gestire vari tipi di dati di provenienza eterogenea. L'implementazione del database è diretta, in quanto si esportano già le classi di entità con le relative istanze utilizzate nel modello HBIM. Lo strumento migliore può essere rappresentato da un database relazionale spaziale (spatial - RDBMS) nelle cui tabelle deve essere presente almeno una colonna chiave primaria per memorizzare l'identificativo dell'oggetto (ID) univoco all'interno della tabella stessa (figg. 4, 5).

Gli sviluppi che si possono documentare dovranno tenere in considerazione la semplificazione di questi passaggi oggi farraginosi per cercare di superarne i limiti, sia di tempo 
Fig. 3. La nuvola di punti del software Autodesk Revit. sia di intrinseca difficoltà. Obiettivo reale della ricerca da completare dovrà continuare a focalizzarsi sulla possibilità di creare un ambiente di lavoro unico, che possa gestire i dati di differenti provenienze senza trovare ostacoli costruiti da differenti software proprietari.
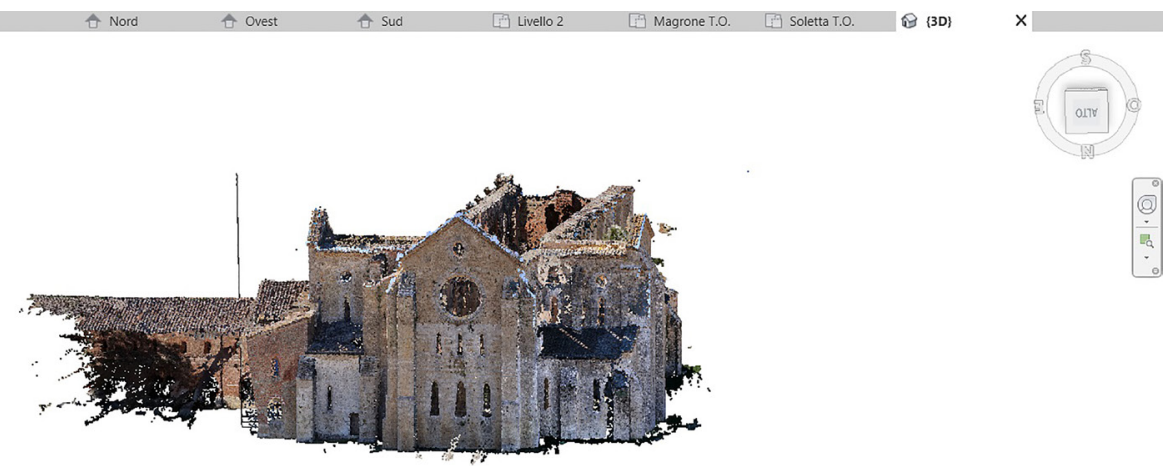

\section{Considerazioni conclusive e prospettive di lavoro}

La realizzazione di uno smart heritage, congruente sia con la metodologia di HBIM, sia con quella mutuabile dall'utilizzo di un sistema informativo geo-referenziato, può consentire un incremento delle potenzialità già garantite dalla tecnologia digitale per la progettazione di processi di riabilitazione, ricostruzione, gestione e manutenzione del patrimonio architettonico. Rendendo più semplice, più chiara e più veloce l'archiviazione ed il controllo di dati geometrici, tecnologici e culturali durante il ciclo di vita di un edificio o di una struttura, la metodologia GIS, integrando il patrimonio di dati vettoriali e dati raster, nonché contenuti informativi a vario livello, può consolidarsi come la principale metodologia da utilizzare per la gestione e la salvaguardia dei manufatti storico-culturali. L'utilizzo congiunto delle tecnologie di rilievo e gestione dei dati offre diversi vantaggi. L'introduzione di accurate e complete rappresentazioni digitali tridimensionali all'interno di appositi cataloghi multimediali permette la visualizzazione immediata dei modelli da parte degli specialisti del settore. La disponibilità di un modello digitale 3D consente non solo la produzione di disegni e stampe in scala 0 al naturale, di qualsivoglia vista e tipo di proiezione, ma soprattutto l'impiego del modello come vero e proprio indice spaziale di un GIS 3D. I molteplici strumenti di supporto forniscono uno strumento al restauro di opere d'arte, permettendo di memorizzare le differenti operazioni d'intervento compiute sul modello virtuale, registrandone le informazioni mediante tecnologie GIS, e creando, quindi, veri e propri database contenenti le caratteristiche dell'oggetto esaminato. La simulazione diretta sul modello digitale consente l'individuazione dell'azione di particolari condizioni atmosferiche, ambientali o anche il deterioramento e l'invecchiamento, valutandone gli effetti sull'opera. I passaggi ad oggi esplorati tra i diversi sistemi, dalle scansioni 3D del reale, al mondo HBIM e poi a quello dei GIS risultano ancora farraginosi e spesso complicati, soprattutto nella prima parte del processo che determina l'importazione, la gestione e il 'riprocessamento' delle nuvole di punti in 3D. I software maggiormente utilizzati sono programmi proprietari, che determinano e costringono i molteplici soggetti coinvolti nel processo a vari passaggi utilizzando famiglie di software spesso costosi e non sempre facili da gestire (specie per il settore pubblico). La base per il funzionamento di questo nuovo Sistema è sicuramente quella già da tempo individuata: garantire l'efficace e costante interazione tra gli attori del processo, quelli afferenti alle diverse discipline, e la condivisione istantanea, già durante la fase di progettazione, delle informazioni e delle modifiche da tutti i soggetti proposte. II modo di garantire queste condizioni deve però ancora essere adeguatamente risolto. 
Fig. 4. Esempio di relazioni all'interno di un database.

Fig. 5. Esempio di relazioni all'interno di un database [Palazzo 2020, p. I49].
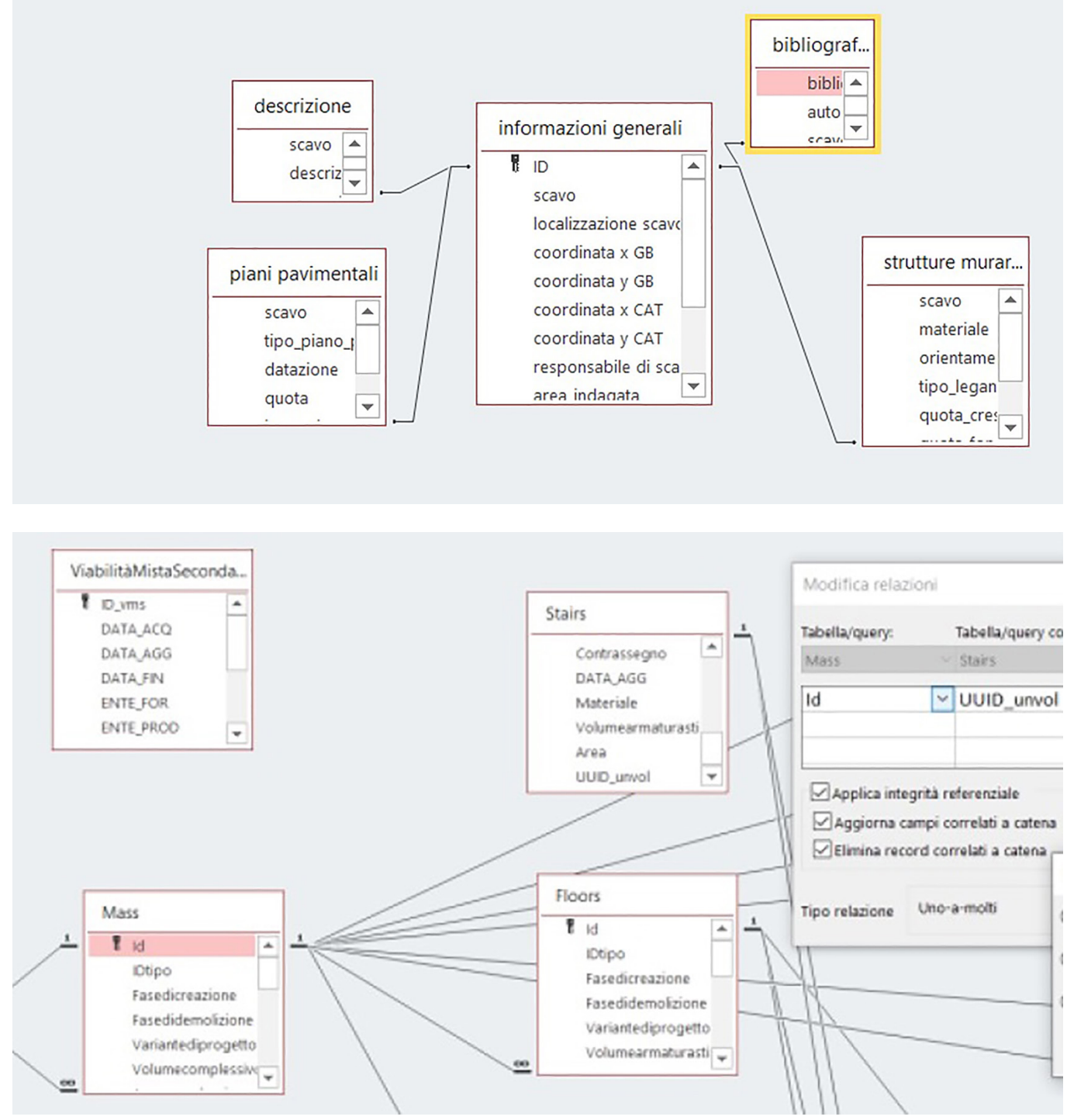

In questa prospettiva il passaggio a software open-source, che è stato ancora poco analizzato e promosso, potrebbe rappresentare una scelta virtuosa. La normativa introdotta per il settore potrebbe infatti aiutare la realizzazione di questo obiettivo (indispensabile per la Pubblica Amministrazione almeno per la fase di controllo finale) tramite la creazione di un unico ambiente, software, organizzato in modo da permettere un approccio collaborativo sia per la gestione delle varie competenze, sia per le attività di coordinamento e condivisione delle decisioni per le valutazioni di fattibilità, costo e qualità.

\section{Note}

[I] Specialmente in ambito di architettura e ingegneria, di ambiente e di design.

[2] Non si intende esatta copia dell'oggetto fisico owviamente, ma dei risultati di scansione ottenuti. È infatti superfluo evidenziare l'inevitabile scostamento che sempre esiste fra oggetto reale e suo rilievo. Si intende invece sottolineare come il procedimento digitale consenta precisioni pressoché prive di errori nella riproduzione grafica dei dati di scansione, precisione che non è evidentemente garantita, allo stesso livello, con le tradizionali tecniche grafiche.

[3] I concetti di Data Base implementabile ed interrogabile sono qui evocati per chiarire la specificità del prodotto digitale fornito come esito del rilievo, concetti che intendono evidenziare sia la necessaria attenzione alla modalità di attuazione del Data Base, sia la sua efficacia di interrogazione continua se la sua implementazione appunto è eseguita in modo appropriato. Non elementi scontati ed approssimativi quindi, ma determinanti per la qualità del Sistema Informativo da costruire. 
[4] II BIM è nato dalla necessità, in fase di progettazione di un nuovo edificio, di poter condividere ed effettuare tutte le analisi necessarie per permettere il trasferimento e lo scambio dei dati resi omogenei per un approccio coordinato tra i vari professionisti. Per quanto riguarda il trattamento dei dati afferenti ad edifici storici, si parla di HBIM, cioè Historic Building Information Modeling [Dore 20 I2] che non è più solo una rappresentazione virtuale e una ricostruzione geometrica del patrimonio, ma $\mathrm{i}$ cui sotto elementi diventano oggetti avanzati corredati di informazioni.

[5] II modello dell'abbazia è stato processato utilizzando fotografie acquisite durante una Summer School organizzata dall'Università di Siena e dalla Fondazione Bruno Kessler di Trento dal 20 al 26 Settembre 2013.

\section{Riferimenti bibliografici}

Baik A., Yaagoubi R., Boehm J. (20I5). Integration of Jeddah Historical BIM and 3D GIS for Documentation and Restoration of Historical Monument. In Int. Arch. Photogramm. Remote Sens. Spat. Inf. Sci, n. 40, pp. 29-34.

Banfi F. Barazzetti L., Previtali M., Roncoroni F. (2017). Historic BIM: a new repository for structural health monitoring. In Int Arch. Photogramm. Remote Sens. Spatial Inf. Sci, n. XLII-5/WI, pp. 269-274.

Bruno N., Rechichi F., Achille C., Zerbi A., Roncella R., Fassi F. (2020). Integration of Historical Gis Data in a HBIM System. In Int. Arch. Photogramm. Remote Sens. Spatial Inf. Sci, n. XLIII-B4, pp. 427-434.

Colucci E. et al. (2020). HBIM-GIS Integration: From IFC to City GML Standard for Damaged Cultural Heritage in a Multiscale 3D GIS. In Appl. Sci, n. I0, pp. I-20.

Diara F., Rinaudo F. (2020). IFC Classification for FOSS HBIM: Open Issues and a Schema Proposal for Cultural Heritage Assets. In Appl. Sci, n. I0, pp. I-23.

Dore C., Murphy M., (20I2). Integration of Historic Building Information Modeling (HBIM) and 3D GIS for recording and managing cultural heritage sites. In Guidi G. I 8th International Conference on Virtual Systems and Multimedia, pp. 369-376. Milan: IEEE.

Logothetis S., Karachaliou E., Valari E., Stylianidis E. (20I8). Open-source cloud-based technologies for BIM. In The Internationa Archives of the Photogrammetry, Remote Sensing and Spatial Information, vol. XLII-2, pp. 607-6I4.

Logothetis S., Valari E., Karachaliou E., Stylianidis E. (2017). Spatial DMBS architecture for a free and open-source BIM. In The International Archives of the Photogrammetry, Remote Sensing and Spatial Information, vol. XLII-2/W5, pp. 467-473.

Palazzo I. (2020). HBIM e GIS 3D per la gestione del patrimonio architettonico: il caso del Sacro Monte di Varallo = HBIM and 3D GIS for the management of built heritage: the case of "Sacro Monte di Varallo". Tesi di laurea magistrale in Ingegneria Edile. Rel. Andrea Maria Lingua, Marco Zerbinatti, Francesca Matrone. Politecnico di Torino.

Pepe M., Costantino D., Restuccia Garofalo A. (2020). An Efficient Pipeline to Obtain 3D Model for HBIM and Structural Analysis Purposes from 3D Point Clouds. In Appl. Sci, n. I0, 1235.

Previtali M., Brumana R., Stanga C., Banfi F. (2020). An Ontology-Based Representation of Vaulted System for HBIM. In Appl. Sci, n. I0, I377, pp. I-20.

Rossi A. (2012). Sons De Piedra. Barcellona Deputaciò de Barcellona. In Rossi A. (Ed.). Suoni nella Pietra, pp. 193- 195. Napoli: Edizioni Scientifiche e Artistiche.

Rossi A. (20|4). Melodie di pietra. Il quadrato claustrale ed il disegno del chiostro di Sant Cugat. Napoli: Edizioni Scientifiche e Artistiche.

Rossi A. (2019). BIM-Oggi-Italia. Padova: Libreria Universitaria.

Tommasi C., Achille C., Fassi F. (2016). From Point Cloud to BIM: a Modelling Challenge in the Cultural Heritage Field. In The International Archives of the Photogrammetry, Remote Sensing and Spatial Information. vol. XLI-B5, pp. 429-436.

Yang X., Lu Y.-C., Murtiyoso A., Koehl M., Grussenmeyer P. (2019). HBIM Modeling from the Surface Mesh and Its Extended Capability of Knowledge Representation. In ISPRS Int. J. Geo-Inf, n. 8, 30 I, pp. I- I7.

Autori

Sara Gonizzi Barsanti, Università degli Studi della Campania Luigi Vanvitelli, sara.gonizzibarsanti@unicampania.it Adriana Rossi, Università degli Studi della Campania Luigi Vanvitelli, adriana.rossi@unicampania.it

Per citare questo capitolo: Gonizzi Barsanti Sara, Rossi Adriana (202I). Scan-to-HBIM e Gis per la documentazione dei beni culturali: un'utile integrazione/Scan-to-Hbim and Gis Technologies for the Documentation of Cultural Heritage: a Useful Integration. In Arena A. Arena M. Mediati D. Raffa P. (a cura di). Connettere. Un disegno per annodare e tessere Linguaggi Distanze Tecnologie. Atti del $42^{\circ}$ Convegno Internazionale dei Docenti delle Discipline della Rappresentazione/Connecting. Drawing for weaving relationship. Languages Distances Technologies. Proceedings of the 42 th International Conference of Representation Disciplines Teachers. Milano: FrancoAngeli, pp. 2353-2366. 


\title{
Scan-to-HBIM and Gis Technologies for the Documentation of Cultural Heritage: a Useful Integration
}

\author{
Sara Gonizzi Barsanti \\ Adriana Rossi
}

Abstract

The use of GIS for the management of geo-spatial data of Cultural Heritage, integrated with Scanto-HBIM procedures, proves to be a very useful tool both for archiving and consultation, and for the conservation of artefacts. In fact, this is closely linked to the regular maintenance of these buildings. To implement it effectively, it is necessary to have a tool that allows you to collect, compare and share all available data on their size, current state of conservation and maintenance or restoration activities carried out over time. The 3D models derived from the surveys become the basis of the conservation and protection project, much more effective if inserted in a GIS "container" of multiple information, divided into specific and univocal categories (objects). Each model is directly accompanied, linked to the geometric definitions, by the relative alphanumeric data (location, materials, technical characteristics, maintenance aspect, structural analysis, estimate of the costs for the restoration, etc.). An Information System formed in this way involves the segmentation of the real three-dimensional models into their structural and decorative parts, individually transformed into HBIM components. It thus becomes constantly implementable and 'interrogable', not as a simple catalogue of information, but also and above all as a tool capable of guaranteeing the extraction, combination and sharing of all the necessary parts.

Keywords

GIS, HBIM, 3D survey, conservation, sharing data.

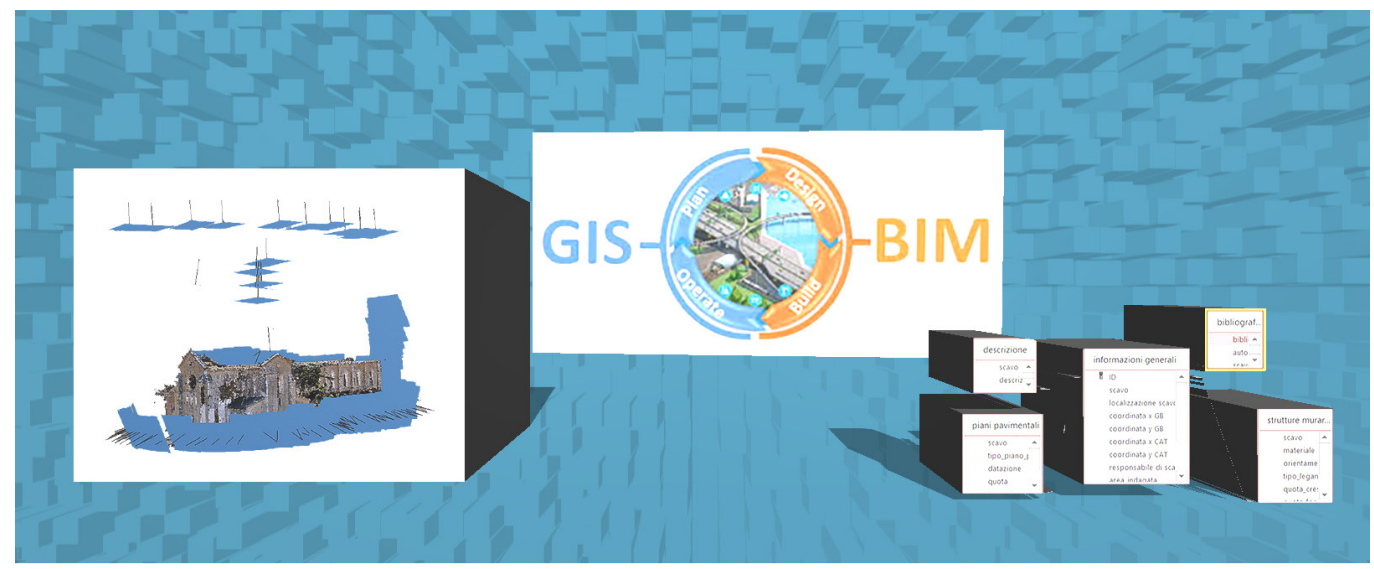




\section{Introduction}

For the protection of Cultural Heritage [I] the first necessary step is the correct and accurate documentation, complete with all the analyses necessary to deliver the most suitable tool to intervene correctly to the managers of the assets themselves. An excellent documentation tool is the one based on optical measurements in three dimensions, which represent a versatile and rigorous tool. Three are the 3D optical acquisition methodologies:

I. $\quad$ passive sensors techniques (image-based methods) as for example photogrammetry;

2. $\quad$ active sensors techniques (range-based methods) as for example laser scanning;

3. the combination of both.

As is known, the choice of the best and most appropriate technique depends on the object or area investigated, the user's experience, the budget, the time available and the objectives set. The photogrammetric technique allows to add the richness provided by the radiometric content to an accurate geometric description in three dimensions. Often, photogrammetric surveys are an optimal solution for carrying out the survey in an economical way and in a short time with the use of digital non-metric cameras, carefully calibrated with appropriate and specific algorithms and procedures. Active sensors, such as laser scanning, are used to perform rigorous investigation of an object or site since, by providing 3D point clouds that can be precisely merged, they allow to obtain the exact metric copy [2] of the object scanned, directly in three dimensions.

It is worth remembering that among the main applications of three-dimensional modelling, already widely used as a support to knowledge, conservation, enhancement and restoration in the field of Cultural Heritage, there are in particular those oriented to the cataloguing and visualization of the objects considered, to the knowledge and analysis of the same and, more operationally, to Computer Aided Restoration. The digitization of the process is already at an advanced stage, but we will mention below how these types of applications could be further enhanced. Furthermore, it is still good to observe that great communicative potential is allowed by those applications, among these mentioned, which make the immersive visualization of the models built as a representation of the investigated reality. Experiences previously conducted by us [Rossi 2012; Rossi 2014; Rossi 2019], in different circumstances and times, on various objects of historical and architectural value, have therefore stimulated the development of this investigation that we present.

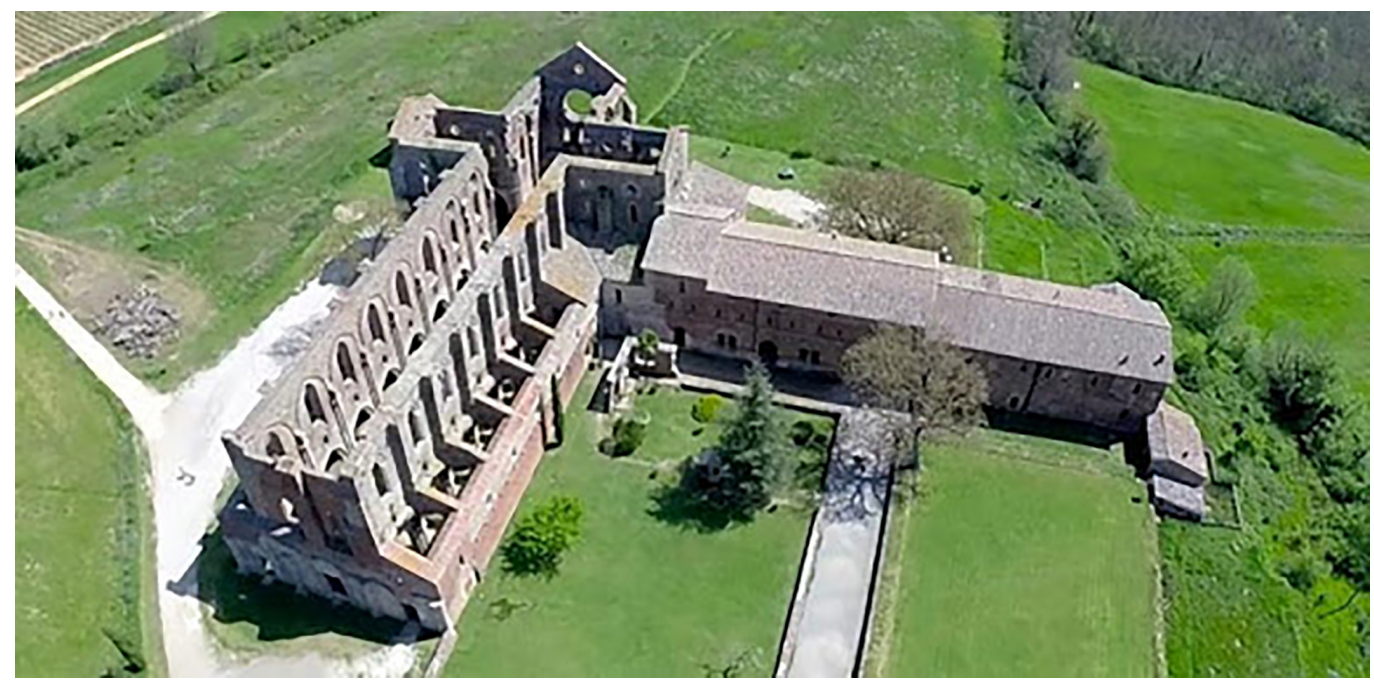




\section{Recent evolutions}

The 3D models derived from the surveys can be inserted into a GIS [Colucci 2020] starting from the segmentation of the real three-dimensional models into their structural and decorative parts within BIM software. These parts will constitute a database that can be constantly implemented [3] and interrogated in the life cycle of the product, creating a catalogue of information, which can also be used for combining and sharing them. By importing, into the software with which the BIM process is managed, the 3D point clouds obtained from the direct survey, the components of the building or architectural complex under investigation, created using the IFC classes (BIM Industry Foundation Classes), their representation is created which constitutes both a coherent geometric modelling of reality and a container for semantic, parametric and relationship descriptions of its elements [Previtali 2020] [4].

For the management of models of cultural artefacts, we now generally speak of HBIM (Historic Building Information System), considering that for these buildings the difficulty of digital realization lies in the intrinsic complexity of these ancient monuments. In fact, they are often composed of constructive elements that are difficult to reproduce with objects obtained from standardized modular productions: the wall structures, for example, are often inclusive of pilasters, half pillars, cornices; the horizontal elements are frequently made with vaults and supported by arches that can change shape and size from floor to floor. For this reason, the survey of the buildings is performed to provide a metrically accurate 3D point cloud of the reality [Yang 2019; Banfi 2017].

The most commonly adopted methodologies for the survey operation are carried out with laser-scanner instrumentation or by photogrammetry; post-processing of the data to create the complete three-dimensional point cloud of the product; modelling of the object in a BIM environment having as a guide the point cloud of the building itself (Scan-to-HBIM). Lately, groups of researchers and developers have started to use solutions capable of including, in addition to metric information, the collection of historical, technological, architectural information referencing them to the digital or raster model and managing them on open source platforms, avoiding proprietary software [Diara 2020; Logothetis 20 I7; Logothetis 20 I 8]. The main problem encountered when you want to integrate GIS with HBIMs is that the two systems manage data with different levels of detail. In fact, GIS were originally born from the need to collect, process and manage an enormous amount of data and territorial information, while BIM systems, initially defined by an evolution of CAD representations, were mainly created to manage a set of information aimed at the decisions to be taken in the field of architectural design. The best method already highlighted in recent works is therefore to combine the two systems into a single platform, which is able to go through the different levels of detail [Bruno 2020].

\section{Methodology}

The Scan-to-HBIM methodology actually involves numerous steps, carried out using different software. Let's analyse a typical example, in which the first step, as we have already seen, consists in the 3D acquisition of the geometry of the artefact through reality-based techniques. The case study we cite refers to the Abbey of San Galgano in the province of Siena [5] (fig. I).

The building was surveyed using terrestrial and drone photogrammetric techniques, to obtain a complete model. The two survey sessions were then processed with Agisoft Metashape software, which uses Structure from Motion (SfM) to obtain a 3D point cloud. The software initially aligns the photographs, calculating their positions in space and at the same time calibrating the internal parameters of the camera, a fundamental step for obtaining undistorted images. Subsequently, the dense cloud of the survey can be calculated which, in the case of the abbey, at the end of the procedure was made up of more than I5 million points (fig. 2). 

Fig. 2. Dense 3D point software sofware combining the close-range and the UAV survey, with the identification of the positions of the cameras (blue square).

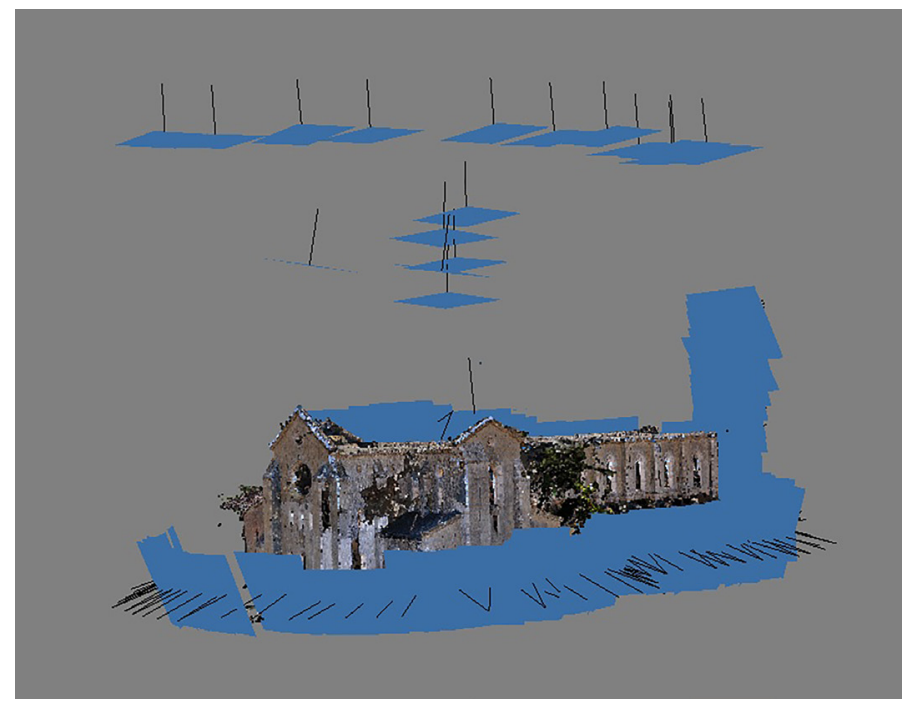

Once the 3D model has been created as in the aforementioned case, it can be imported into the BIM environment for the subsequent parametric modelling steps, necessary to have a model, complete but light and manageable in the GIS environment.

Today the most widely used software for BIM / HBIM modelling is certainly Autodesk's Revit, which allows you to import point clouds, created externally with specific software, that can then be remodelled and analysed. This step currently presents a problem, as Revit reads only and exclusively two formats, *.rcs and *.rcp, while the photogrammetric software exports in common formats (*.ply, *.obj, *.xyz) as well as in some formats compatible with CAD software. In order to transform the photogrammetric file into one compatible with the BIM software, it was therefore necessary to go through another Autodesk software, Recap, which by reading the *.xyz files, is able to export them in the format compatible with Revit (fig. 3).

There are two procedures usually used to model a 3D point cloud in order to make it suitable for using it as a parametric model in a BIM software:

a. import the cloud into modelling software such as Autocad or Rhinoceros, create profiles, model the building using surfaces or NURBS and then import this model into a BIM software;

b. use object-oriented parametric modelling using BIM processes directly [Tommasi 2016].

As seen, the possibility of obtaining parametric models, divided into specific classes with their own characteristics and information, is a fundamental element for the use of HBIMs in the conservation and restoration of cultural heritage and for this reason several researches are recently analysing their various potentialities [Pepe 2020; Previtali 2020]

Reliable utilities for the digital documentation of architectural complexes can also be realized in the correct connection of these models to a GIS environment. The difficulty in these steps is still due to the fact that the two types of systems manage data at different scales: environmental those of the GIS, structural those of the HBIM. For now, the link between the two methodologies takes place at the level of an interoperable and multi-scale relational database, which responds to the need to archive and manage various types of data of heterogeneous origin. The implementation of the database is direct, as the entity classes are already exported with the related instances used in the HBIM model. The best tool can be represented by a spatial relational database (spatial - RDBMS) in whose tables there must be at least one primary key column to store the unique object identifier (ID) within the table itself (figs. 4, 5). 
The developments that can be documented will have to take into consideration the simplification of these now cumbersome passages in order to try to overcome their limits, both of time and intrinsic difficulty. The real objective of the research to be completed will have to continue to focus on the possibility of creating a unique work environment, which can manage data from different sources without finding obstacles built by different proprietary software.

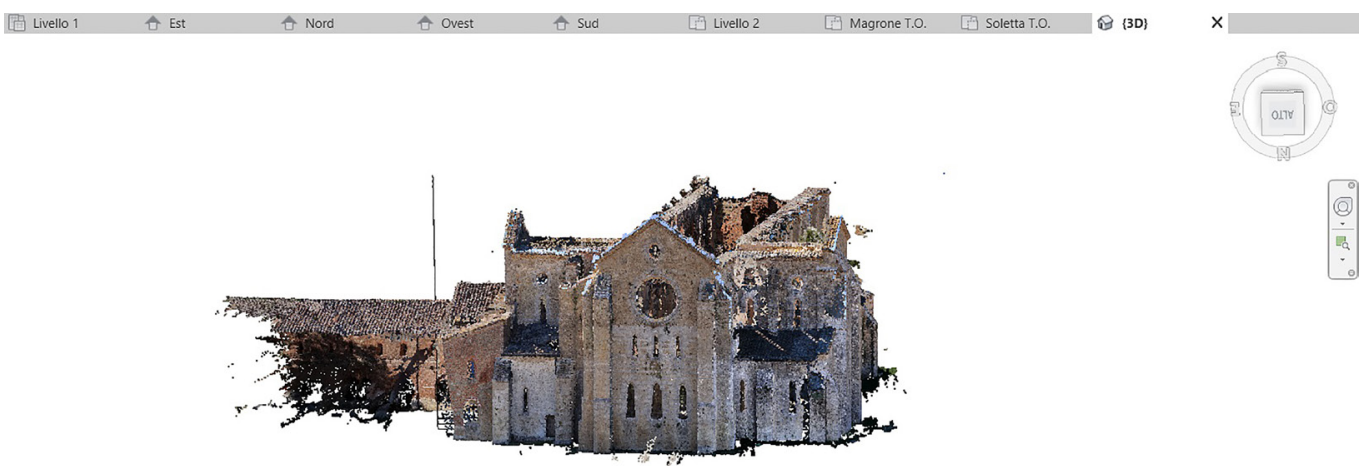

\section{Concluding remarks and future work}

The creation of a 'smart Heritage', congruent both with the HBIM methodology and with that which can be borrowed from the use of a georeferenced information system, can allow an increase in the potential already guaranteed by digital technology for the design of rehabilitation and reconstruction processes, management and maintenance of the architectural heritage. Making it easier, clearer and faster the storage and control of geometric, technological and cultural data during the life cycle of a building or structure, the GIS methodology, integrating the heritage of vector and raster data, as well as information content at various levels, can be consolidated as the main methodology to be used for the management and preservation of historical and cultural artefacts. The joint use of survey and data management technologies offers several advantages. The introduction of accurate and complete three-dimensional digital representations within special multimedia catalogues allows immediate viewing of the models by specialists in the sector.The availability of a 3D digital model allows not only the production of drawings and prints in scale or natural, of any view and type of projection, but above all the use of the model as a real spatial index of a 3D GIS. The multiple support devices provide a tool for the restoration of works of art, allowing to memorize the different intervention operations carried out on the virtual model, recording the information using GIS technologies, and thus creating real databases containing the characteristics of the object examined. The direct simulation on the digital model allows the identification of the action of particular atmospheric and environmental conditions or even deterioration and aging, evaluating the effects on the work.

The steps explored to date between the different systems, from 3D scans of reality, to the HBIM world and then to that of GIS, are still cumbersome and often complicated, especially in the first part of the process that determines the import, management and reprocessing of 3D point clouds. The most used software are proprietary ones, which determine and force the multiple subjects involved in the process to various steps using families of software that are often expensive and not always easy to manage (especially for the public sector). The basis for the functioning of this new System is certainly the one that has already been identified for some time: guaranteeing the effective and constant interaction between the actors of the process, those belonging to the various disciplines, and the instant sharing, already during the design phase, of information and the changes proposed by all the subjects. However, the 
Fig. 4. Example of relations inside a database.

Fig. 5. Example of relations inside a database [Palazzo 2020, p. 149].
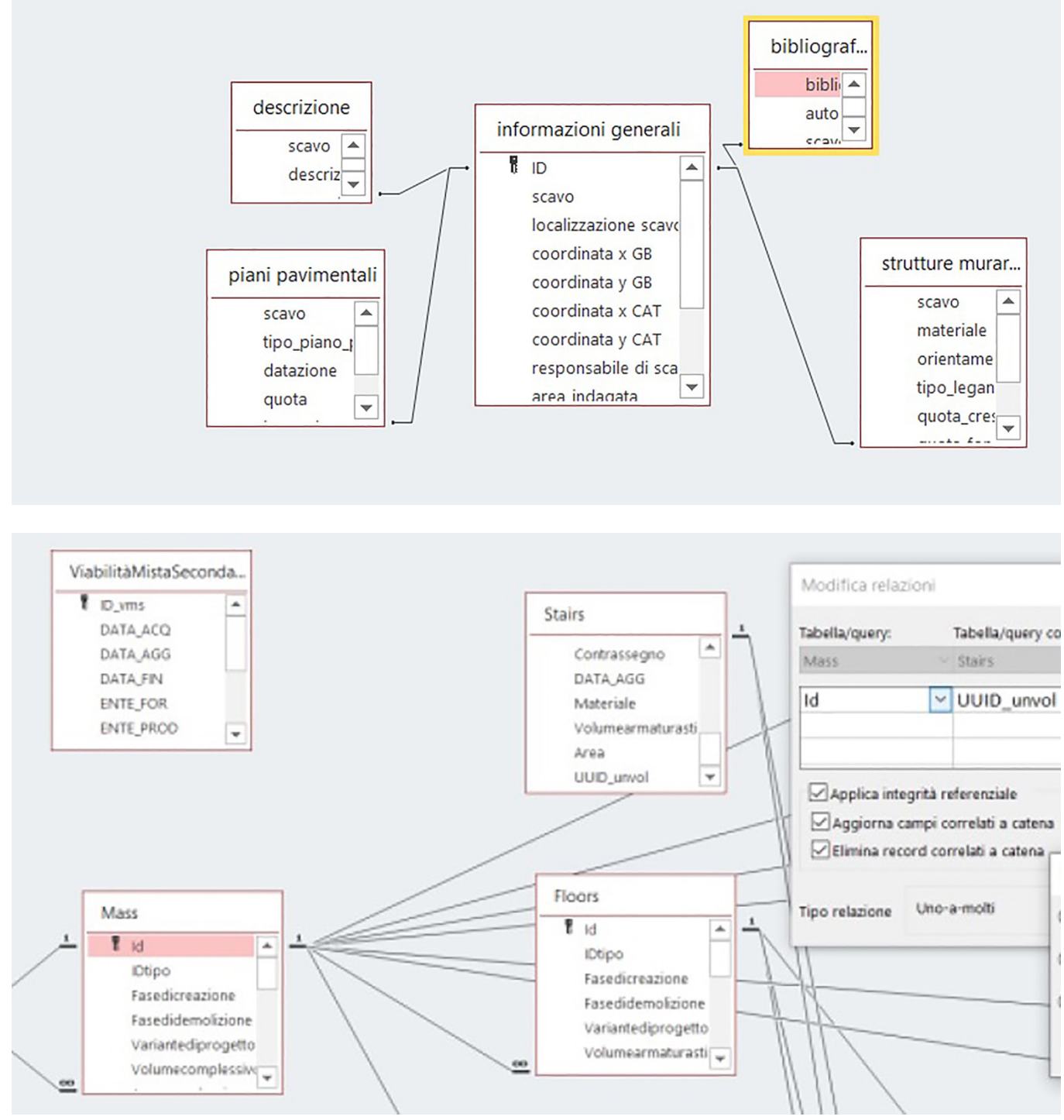

way to guarantee these conditions has yet to be adequately resolved. In this perspective, the transition to open-source software, which has been yet slightly analysed and promoted, could represent a virtuous choice. The legislation introduced for the sector could in fact help the realization of this objective (indispensable for the Public Administration at least for the final control phase) by creating a single environment, software, organized in such a way as to allow a collaborative approach both for the management of the various skills, for the coordination and sharing of decisions for the feasibility, cost and quality assessments.

\section{Notes}

[I] Especially in the fields of architecture and engineering, environment and design.

[2] Obviously, it is not an exact copy of the physical object, but of the scan results obtained. It is in fact superfluous to highlight the inevitable deviation that always exists between the real object and its survey. On the other hand, it is intended to underline how the digital process allows almost error-free precision in the graphic reproduction of the scan data, a precision which is obviously not guaranteed, at the same level, with traditional graphic techniques.

[3] The concepts of an implementable and searchable Data Base are evoked here to clarify the specificity of the digital product provided as a result of the survey, concepts that intend to highlight both the necessary attention to the implementation methods of the Data Base, and its effectiveness of continuous interrogation if implementation is done appropriately. Not obvious and approximate elements therefore, but decisive for the quality of the Information System to be built. 
[4] BIM was born from the need, during the design phase of a new building, to be able to share and carry out all the necessary analyses to allow the transfer and exchange of homogeneous data for a coordinated approach between the various professionals. Regarding the processing of data relating to historic buildings, we speak of HBIM, that is Historic Building Information Modelling [Dore 20I2] which is no longer just a virtual representation and a geometric reconstruction of the heritage, but whose sub-elements become advanced objects equipped with information.

[5] The model of the abbey was processed using photographs acquired during a Summer School organized by the University of Siena and the Bruno Kessler Foundation of Trento from 20 to 26 September 2013.

\section{References}

Baik A., Yaagoubi R., Boehm J. (20 I5). Integration of Jeddah Historical BIM and 3D GIS for Documentation and Restoration of Historical Monument. In Int. Arch. Photogramm. Remote Sens. Spat. Inf. Sci, n. 40, pp. 29-34.

Banfi F. Barazzetti L., Previtali M., Roncoroni F. (2017). Historic BIM: a new repository for structural health monitoring. In Int Arch. Photogramm. Remote Sens. Spatial Inf. Sci, n. XLII-5/WI, pp. 269-274.

Bruno N., Rechichi F., Achille C., Zerbi A., Roncella R., Fassi F. (2020). Integration of Historical Gis Data in a HBIM System. In Int Arch. Photogramm. Remote Sens. Spatial Inf. Sci, n. XLIII-B4, pp. 427-434.

Colucci E. et al. (2020). HBIM-GIS Integration: From IFC to City GML Standard for Damaged Cultural Heritage in a Multiscale 3D GIS. In Appl. Sci, n. I0, pp. I-20.

Diara F., Rinaudo F. (2020). IFC Classification for FOSS HBIM: Open Issues and a Schema Proposal for Cultural Heritage Assets. In Appl. Sci, n. I0, pp. I-23

Dore C., Murphy M., (20I2). Integration of Historic Building Information Modeling (HBIM) and 3D GIS for recording and managing cultural heritage sites. In Guidi G. I 8th International Conference on Virtual Systems and Multimedia, pp. 369-376. Milan: IEEE.

Logothetis S., Karachaliou E., Valari E., Stylianidis E. (20I8). Open-source cloud-based technologies for BIM. In The Internationa Archives of the Photogrammetry, Remote Sensing and Spatial Information, vol. XLII-2, pp. 607-6I4.

Logothetis S., Valari E., Karachaliou E., Stylianidis E. (2017). Spatial DMBS architecture for a free and open-source BIM. In The International Archives of the Photogrammetry, Remote Sensing and Spatial Information, vol. XLII-2/W5, pp. 467-473.

Palazzo I. (2020). HBIM e GIS 3D per la gestione del patrimonio architettonico: il caso del Sacro Monte di Varallo = HBIM and 3D GIS for the management of built heritage: the case of "Sacro Monte di Varallo". Tesi di laurea magistrale in Ingegneria Edile. Rel. Andrea Maria Lingua, Marco Zerbinatti, Francesca Matrone. Politecnico di Torino.

Pepe M., Costantino D., Restuccia Garofalo A. (2020). An Efficient Pipeline to Obtain 3D Model for HBIM and Structural Analysis Purposes from 3D Point Clouds. In Appl. Sci, n. I0, 1235

Previtali M., Brumana R., Stanga C., Banfi F. (2020). An Ontology-Based Representation of Vaulted System for HBIM. In Appl. Sci, n. I0, I377, pp. I-20.

Rossi A. (2012). Sons De Piedra. Barcellona Deputaciò de Barcellona. In Rossi A. (Ed.). Suoni nella Pietra, pp. 193- 195. Napoli: Edizioni Scientifiche e Artistiche.

Rossi A. (20|4). Melodie di pietra. Il quadrato claustrale ed il disegno del chiostro di Sant Cugat. Napoli: Edizioni Scientifiche e Artistiche.

Rossi A. (2019). BIM-Oggi-Italia. Padova: Libreria Universitaria.

Tommasi C.. Achille C., Fassi F. (2016). From Point Cloud to BIM: a Modelling Challenge in the Cultural Heritage Field. In The International Archives of the Photogrammetry, Remote Sensing and Spatial Information. vol. XLI-B5, pp. 429-436.

Yang X., Lu Y.-C., Murtiyoso A., Koehl M., Grussenmeyer P. (2019). HBIM Modeling from the Surface Mesh and Its Extended Capability of Knowledge Representation. In ISPRS Int. J. Geo-Inf, n. 8, 30 I, pp. I- I7.

\footnotetext{
Authors

Sara Gonizzi Barsanti, Università degli Studi della Campania Luigi Vanvitelli, sara.gonizzibarsanti@unicampania.it Adriana Rossi, Università degli Studi della Campania Luigi Vanvitelli, adriana.rossi@unicampania.it
}

To cite this chapter. Gonizzi Barsanti Sara, Rossi Adriana (202I). Scan-to-HBIM e Gis per la documentazione dei beni culturali: un'utile integrazione/Scan-to-Hbim and Gis Technologies for the Documentation of Cultural Heritage: a Useful Integration. In Arena A. Arena M Mediati D. Raff P (a cura di) Connettere Un disegno per annodare e tessere Linguagoi Distanze Tecnologie. Atti del $42^{\circ}$ Convegno Internazionale dei Docenti delle Discipline delta Rappresentazionel Conference of Representation Disciplines Teachers. Milano: FrancoAngeli. pp. 2353-2366. 